Tersedia Secara Online di

\title{
Kuat Tekan Pelat Beton Menggunakan Pasir Wlingi Dan Wiremesh Diameter 4 Mm
}

\author{
M. Vricilia ${ }^{1 *}$, A. Ridwan ${ }^{2}$, A. I. Candra ${ }^{3}$ \\ ${ }^{1 * 2,3}$ Fakultas Teknik, Universitas Kadiri. \\ Email : 1* memevricilia@gmail.com.
}

\begin{tabular}{ll} 
A R T I C L E I N F O \\
\hline Article history: \\
Artikel masuk $: 19-9-2020$ \\
Artikel revisi & $: 26-9-2020$ \\
Artikel diterima & $: 28-9-2020$ \\
\hline
\end{tabular}

Keywords :

Reinforced Concrete, Tensile Strength, Compressive Strength, Wiremesh

\section{Style IEEE dalam mensitasi artikel ini: [5] G. Li and J. Cheng, "A generalized analytical modeling of grid stiffened composite structures, "J. Compos. Mater., vol. 41, no. 24, pp. 2939 2969, 2007.}

\begin{abstract}
A B S TRACT
Reinforced concrete is a combination of concrete and steel, where reinforcing steel provides tensile strength that concrete does not possess. Wlingi sand is sand that has a high level of silica. The function of silica to functional extender adds durability and anti-corrosion and anti-weathering properties. The purpose of this study is to find out the strong press, strong pull wire mesh, cracks, cracks, and faults and to find out if the test results can qualify as concrete plates-testing on test objects by the required SNI. The results showed that the compressive strength test value got an average value (28.38 Mpa), the wiremesh tensile strength test had average yield stress (393.42 Mpa), and tensile stress (569.30), and the seepage test were obtained the mean value (0.45\%). The test for cracks and fractures obtained an average (1.72 Mpa) (2.18 Mpa). Test results showed wire mesh steel could be used as a concrete plate reinforcing because it has tensile voltage and melt voltage exceeding the minimum allowable limit of $390 \mathrm{Mpa}$ and 240 Mpa.
\end{abstract}

\section{A B S T R A K}

Beton bertulang adalah kombinasi antara beton dan baja, dimana baja tulangan memberikan kekuatan tarik yang tidak dimiliki beton. Pasir wlingi merupakan pasir yang memiliki kadar silika yang cukup tinggi, fungsi dari silika untuk ekstender fungsional menambah daya tahan dan sifat anti korosi serta anti pelapukan.Tujuan dari penelitian ini adalah untuk mengetahui kuat tekan, kuat tarik wiremesh, rembesan, retakan dan patahan dan untuk mengetahui apakah hasil pengujian dapat memenuhi syarat sebagai pelat beton. Pengujian pada benda uji sesuai dengan SNI yang disyaratkan. Pengujian dilakukan saat umur beton 28 hari dengan 3 benda uji berbentuk balok ukuran $\mathrm{P} \times \mathrm{L} \times \mathrm{t}=60 \times 20 \times 10(\mathrm{~cm})$. Hasil penelitian menunjukkan bahwa pengujian kuat tekan didapat nilai rata-rata (28,38 Mpa), pengujian kuat tarik wiremesh memiliki nilai ratarata tegangan leleh $(393,42 \mathrm{Mpa})$ serta tegangan tarik $(569,30)$, pada pengujian rembesan didapat nilai rata-rata $(0,45 \%)$, pengujian retakan dan patahan didapat rata-rata (1,72 Mpa) 
(2,18 Mpa). Hasil pengujian menunjukkan baja wiremesh dapat digunakan sebagai tulangan pelat beton karena memiliki tegangan tarik dan tegangan leleh melebihi batas minimum yang diijinkan yaitu $390 \mathrm{Mpa}$ dan $240 \mathrm{Mpa}$.

\section{Pendahuluan}

Proyek pembangunan di Indonesia mengalami perkembangan yang signifikan. Perkembangan tersebut terbukti dari maraknya pembangunan gedung, jembatan, bendungan dan konstruksi lainnya. Dampak perkembangan tersebut memunculkan inovasi-inovasi baru, terutama peningkatan kebutuhan beton sebagai bahan konstruksi yang paling diminati [1] [2]. Penelitian perihal penambahan serat baja yang dimasukkan ke dalam campuran beton, sudah menjadi perhatian sejak pertama kali dipublikasikan pada tahun 1960. Beton berserat baja atau steel fiber reinforced concrete (SRFC) sudah banyak diaplikasikan oleh beberapa penelitian, penelitian tersebut diaplikasikan pada struktur pelat, dengan atau tanpa penambahan tulangan. Sejumlah penelitian perihal beton berserat baja telah diakui sebagai ASTM (American Standard Test Method) dan digunakan sebagai acuan di berbagai Negara [3].

Pelat lantai adalah salah satu komponen penting untuk struktur gedung [4], karena memiliki tugas ganda sebagai penerima dan penyalur beban serta pembagian ruang [5]. Pelat lantai pada umumnya memiliki ketebalan yang relatif tipis bila dibandingkan dengan panjang bentangnya sehingga sifat kaku dari plat sangat kecil yang mengakibatkan terlalu besarnya lendutan. Untuk pencegahan lendutan yang terlalu besar pada pelat lantai dilakukan berbagai alternative, salah satunya memanfaatkan sistem kisi yang biasa dikenal dengan struktur gird [6]. Struktur gird bisa digunakan pada gedung-gedung di Indonesia, struktur ini biasanya digunakan untuk bentangan yang besar serta memiliki sifat utama mendistribusikan beban pada dua arah dengan seimbang. Struktur gird menggunakan bahan dari konstruksi beton bertulang dengan ketebalan yang cukup tipis serta biaya yang lebih hemat [7].

Inovasi yang dapat dilakukan adalah menambahkan material beton dengan material yang mudah didapat dan harga yang terjangkau. Adapun alternative bahan yang digunakan pada penelitian ini tulangan Wiremesh dengan diameter $4 \mathrm{~mm}$. Peneliti terdahulu membahas tentang penggunaan wiremesh [8][9][10], Retrofit wiremesh [11][12], SSC [13], GFRP (Glass Fiber Reinforced Polymer) [14]. Barang tersebut banyak tersebar di toko bangunan, sehingga barang tersebut mudah didapatkan. Dari sini penulis dapat melihat perlunya pemanfaatan secara maksimal terhadap Wiremesh berkaitan dengan fungsinya yang bisa digunakan untuk bahan pengganti tulangan yang harganya terus meningkat. Tujuan dari penelitian ini adalah untuk mengetahui kuat tekan, kuat tarik wiremesh, absorpsi (rembesan) serta retakan patahan dan untuk mengetahui apakah hasil dari pengujian memenuhi syarat 
sebagai pelat beton.

\section{Studi Literatur}

\subsection{Beton}

Beton merupakan campuran antara semen portland, agregat halus, agregat kasar, air dengan tambahan campuran atau tidak yang mampu membuat massa padat. Beton merupakan konstruksi yang dominan digunakan pada struktur bangunan, baik konstruksi gedung, sarana transportasi bangunan air dan bangunan lainnya [15][16].

Beton bertulang merupakan beton yang ditulangi dengan luas dan jumlah tulangan yang tidak kurang dari nilai minimum, disyaratkan dengan atau tanpa prategang, direncanakan berdasarkan asumsi bahwa kedua material bekerja sama untuk menahan gaya yang bekerja [8], apabila kedua material tersebut digabungkan akan menghasilkan bahan bangunan baru dan memiliki sifat yang lebih baik.

\subsection{Material Penyusun Beton}

Material penyusun beton merupakan salah satu yang mempengaruhi kuat tekan beton [17], bahan-bahan tersebut meliputi, air, semen, agregat halus dan agregat kasar. Bahan-bahan tersebut dibedakan menjadi dua kelompok, bahan aktif dan bahan pasif. Bahan aktif terdiri dari air dan semen sedangkan bahan pasir terdiri dari agregat halus dan agregat kasar, bahan aktif disebut sebagai pengikat dan bahan pasif sebagai pengisi [18][19].

1. Air

Air difungsikan untuk memicu proses kimiawi semen, memberikan kemudahan untuk pengerjaan beton serta digunakan untuk membasahi agregat. Air harus digunakan dengan tepat, jika kelebihan bisa mengakibatkan kebanyakan gelembung air setelah hidrasi dan apabila kekurangan dapat mengakibatkan proses hidrasi tidak tercapai.

2. Semen

Semen merupakan hasil industri yang terdiri dari campuran dan susunan yang berbeda, semen dibedakan menjadi 2 semen hidrolik dan non hidrolik. Semen hidrolik, semen yang mampu mengeras dan mengikat dengan air sedangkan. Semen non hidrolik, semen yang tidak bisa mengeras dan mengikat dengan air namun bisa mengikat dengan udara [20].

3. Agregat

Agregat merupakan bahan pengisi dalam campuran beton, agregat merupakan butiran mineral alami. Diperkirakan agregat yang terkandung dalam campuran beton mencapai 
mencapai 60-75\% dari volume beton [21]. Agregat sendiri dibedakan menjadi 2 yaitu:

a. Agregat Halus

Agregat halus merupakan butiran mineral alami berukuran sangat kecil, bisa disebut dengan pasir, ukurannya tidak lebih dari 4,8 $\mathrm{mm}$ [22].

b. Sgregat Kasar

Agregat kasar memiliki peranan penting untuk membuat beton, berfungsi mengurangi volume dari pasta semen dan sebagai penentu kekuatan suatu beton, memiliki ukuran lebih dari $4,8 \mathrm{~mm}$.

\section{Wiremesh}

Wiremesh merupakan jaringan kawat las yang memiliki kualitas tinggi, setiap detail wiremesh dibuat menggunakan pengawasan yang teliti, mulai dari pemilihan material melalui kontrol yang ketat lalu besi dilas menggunakan alat las otomatis berteknologi tinggi dan akan menghasilkan wiremesh yang berkualitas bagus [23]. Keuntungan dari menggunakan wiremesh, mempercepat proses konstruksi, mutu bangunan bisa lebih baik serta meminimalisir biaya karena harga tulangan selalu naik setiap periode.

\subsection{Kuat Tekan}

Pengujian kuat tekan menggunakan palu beton adalah dengan mengetahui kuat tekan beton tanpa merusak beton itu sendiri. Pengujian menggunakan alat ini memiliki banyak kelebihan yaitu, biaya murah, pengukuran bisa dilakukan dengan cepat, praktis serta tidak merusak beton. Namun alat ini juga memiliki kekurangan antara lain, hasil pengujian dipengaruhi oleh kerataan permukaan, kelembaban beton, umur beton, jenis agregat kasar, sulit mengkalibrasi hasil pengujian, tingkat kendalanya rendah serta hanya memberikan informasi mengenai karakteristik beton pada bagian luar saja(SNI 03-4430-1997) [24].

Tidak ada rumus untuk perhitungan kuat tekan dari pengujian menggunakan hammer test. Cara perhitungan hammer test yaitu, hasil yang berbeda lebih dari 6 satuan dari rata-rata 10 titik bacaan diabaikan dan tetukan hasilnya dari nilai rata-rata pembacaan data yang memenuhi syarat. Jika 2 bacaan memiliki perbedaan lebih dari 6 satuan maka seluruh pembacaan dibatalkan lalu cari daerah lain untuk pengujian(RSNI 4830:2000) [25].

\subsection{Kuat Tarik Besi}

Tulangan yang bisa digunakan yaitu, baja tulangan dan kawat baja saja (SNI 2052:2014). Perhitungan nilai tarik leleh dan tegangan tarik putus bisa dihitung menggunakan rumus persamaan (SNI 07-2529-1991) [26]: 
a. Tegangan tarik putus Fs :

$$
f s=\frac{P \text { maks }}{\text { Aso }}
$$

b. Tegangan tarik leleh fy :

$$
f s=\frac{P \text { maks }}{\text { Aso }}
$$

c. Regangan maksimum :

$$
f s=\frac{P \text { maks }}{\text { Aso }}
$$

d. Kontraksi penampang :

$$
f s=\frac{P \text { maks }}{\text { Aso }}
$$

Dimana :

fs $\quad=$ Tegangan tarik putus $(\mathrm{MPa})(\mathrm{N})$

$\mathrm{P}$ maks $=$ Kuat tarik putus $(\mathrm{N})$

Aso $\quad=$ Luas penampang benda uji semula $\left(\mathrm{mm}^{2}\right)$

Asu = Luas penampang benda uji setelah pengujian $\left(\mathrm{mm}^{2}\right)$

Fy $\quad=$ Tegangan tarik leleh $(\mathrm{N})$

Py $\quad=$ Kuat tarik leleh $(\mathrm{N})$

E maks = Regangan maksimum benda uji saat putus (\%)

$\mathrm{Iu}=$ Panjang benda uji setelah pengujian $(\mathrm{mm})$

Io $\quad=$ Panjang benda uji semula $(\mathrm{mm})$

S $\quad=$ Kontraksi penampang benda uji saat putus

\subsection{Absorsi (Rembesan)}

Absorpsi merupakan tingkat daya serap air terhadap permukaan beton, menurut (SNI 03-6433-2000) perhitungan untuk besarnya penyerapan air menggunakan rumus [27] :

Absorpsi $=\frac{B-A}{A} \times 100 \%$
A $\quad=$ Berat benda uji kering $(\mathrm{Kg})$
$\mathrm{B}=$ Berat benda uji setelah direndam $(\mathrm{Kg})$ 


\subsection{Retakan dan Patahan}

Retakan merupakan keadaan pisah atau pecahnya struktur tanpa adanya keruntuhan. Tingkat kerusakan akibat retak tergantung pada banyaknya retakan dan endapan disekitarnya. Untuk pengujian retakan dan patahan ini mengacu pada kuat tarik lentur beton. Kuat tarik lentur merupakan kemampuan balok beton yang terletak pada dua perletakkan guna menahan gaya dengan arah tegak lurus sumbu benda uji yang diberikan padanya sampai benda uji dinyatakan patah pada satuan Mega Pascal (MPa) gaya pada tiap satuan luas (SNI 03-4431-1997) [28]. Pada penelitian ini tidak dilakukan perhitungan, hanya mencari balok beton mengalami retakan dan patahan saat menerima beban berapa (MPa).

\section{Metodologi Penelitian}

Metode yang digunakan dalam penelitian ini adalah metode eksperimental di laboratorium serta tinjauan pustaka penelitian terdahulu. Penelitian eksperimental dilakukan di Laboratorium Teknik Sipil Universitas Kadiri dengan mengacu sesuai standar SNI.

\subsection{Rencana Penelitian}

Metode eksperimental dilakukan dengan pembuatan 3 benda uji berbentuk balok dengan ukuran $\mathrm{P} \times \mathrm{L} \times \mathrm{t}=60 \times 20 \times 10(\mathrm{~cm})$. Material yang digunakan meliputi air, semen, agregat halus (pasir dari wlingi blitar), agregat kasar (koral dari kedak) dan baja wiremesh sebagai tulangan. Pengujian kuat tekan menggunakan hammer test, absorpsi serta retakan dan patahan yang mengacu pada kuat tarik lentur beton, pengujian dilakukan saat umur beton 28 hari.

\subsection{Alur Penelitian}

Tahap pertama yang dilakukan adalah mempersiapkan bahan penyusun beton, jika bahan sudah siap lakukan pemeriksaan benda uji agregat halus dan agregat kasar. Jika bahan yang diperiksa memenuhi syarat pemakaian sesuai SNI yang disyaratkan. Setelah itu pembuatan benda uji sesuai cetakan yang direncanakan, balok dengan ukuran $\mathrm{P} \times \mathrm{L} \times \mathrm{t}=$ $60 \times 20 \times 10(\mathrm{~cm})$, padatkan dengan menggunakan alat penusuk baja dan dilakukan penggoyangan dengan cara manual yaitu pemberian ketukan pada bagian luar cetakan. Diamkan selama 2 hari, setelah beton kering selanjutnya dilakukan proses perawatan (curing) beton. Setelah 28 hari dilakukan pengujian pada benda uji sesuai pengujian yang akan dilakukan meliputi, kuat tekan, kuat Tarik besi wiremesh, rembesan (absorpsi) serta retakan patahan. Tahap penelitian akan disajikan pada Gambar 1 berikut : 


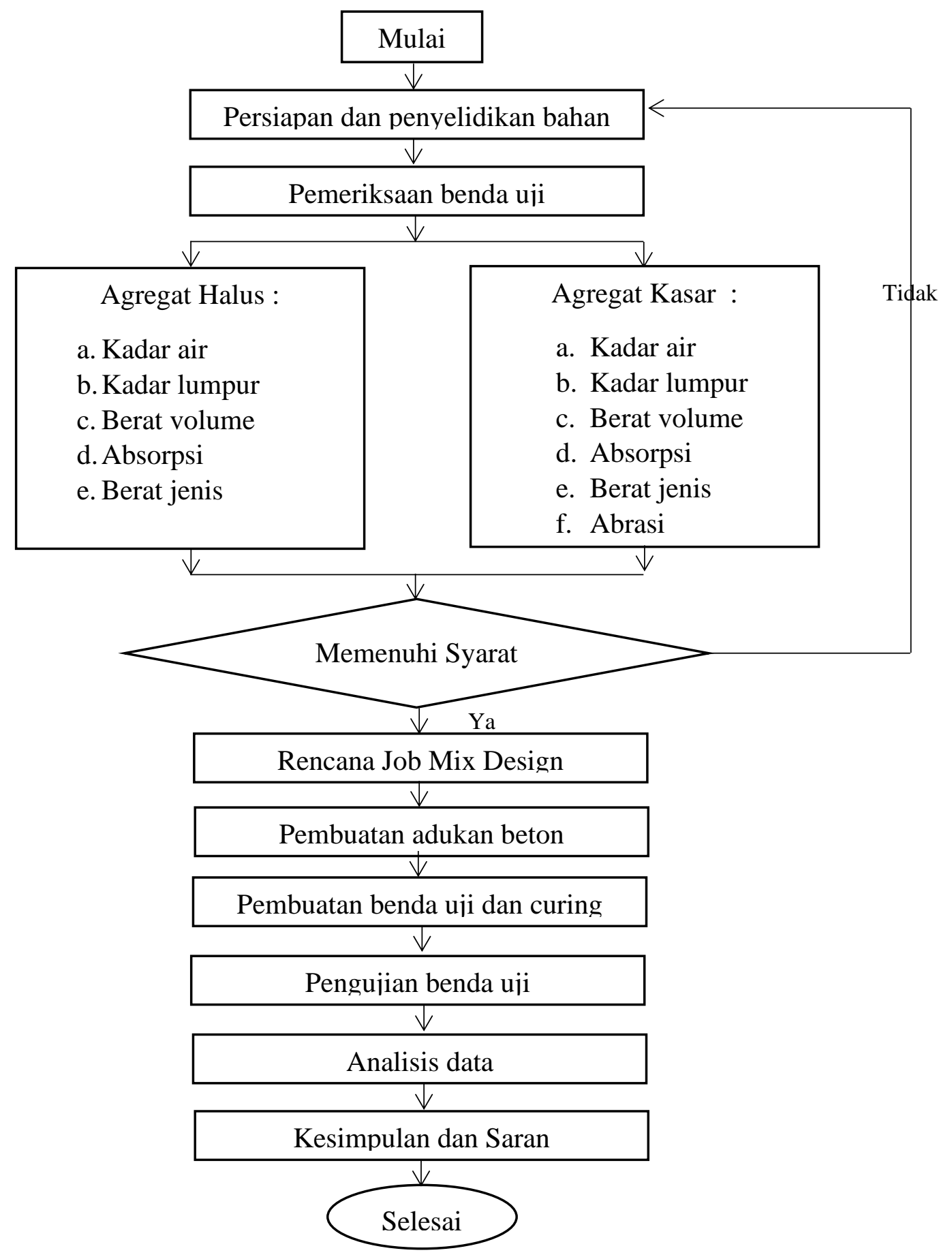

Sumber : Analisa Alur Penelitian.

Gambar 1. Alur Penelitian 


\section{Hasil dan Diskusi}

Hasil dari pembahasan dalam penelitian ini meliputi hasil pengujian material, berat jenis, kuat tekan, tarik baja, rembesan (absorpsi) dan retakan patah yang akan dibahas.

\subsection{Pengujian Agregat Halus}

1. Kadar Air (SNI 1971:2011)

Hasil pengujian kadar air diperoleh hasil 2,7\%. Berdasarkan SNI 1971:2011 kadar air yang disyaratkan berkisar antara $2 \%-5 \%$.

2. Kadar Lumpur (SNI 03-4428-1997)

Hasil pengujian kadar lumpur diperoleh hasil 4,3\%. Berdasarkan SNI 03-4428-1997 kadar lumpur yang disyaratkan $5 \%$.

3. Berat Volume (SNI 1973:2008)

Hasil pengujian berat volume diperoleh hasil 1,77 kg/lt (lepas) dan 1,8 kg/lt (padat). Berdasarkan SNI 1973:2008 berat volume yang disyaratkan untuk lepas dan padat 1,6-1,9 $\mathrm{kg} / \mathrm{lt}$.

4. Absorpsi (SNI 1970:2008)

Hasil pengujian absorpsi diperoleh hasil 0,02\%. Berdasarkan SNI 1970:2008 absorpsi yang disyaratkan $2 \%$.

5. Berat Jenis (SNI 1970:2008)

Hasil pengujian berat jenis diperoleh hasil berat jenis curah kering 2,97 yang disyaratkan $(1,6-3,3)$, berat jenuh kering permukaan 3,03 yang disyaratkan $(1,6-3,4)$ dan berat jenis semu 3,16 dan yang disyaratkan (1,6-3,8) menurut SNI 1970:2008.

\subsection{Pengujian Agregat Kasar}

\section{Kadar Air (SNI 1971:2011)}

Hasil pengujian kadar air diperoleh hasil 1,6\%. Berdasarkan SNI 1971:2011 kadar air yang disyaratkan berkisar antara $0,5 \%-2 \%$.

2. Kadar Lumpur (SNI 03-4142-1996)

Hasil pengujian kadar lumpur diperoleh hasil 0,6\%. Berdasarkan SNI 03-4142-1996 kadar lumpur yang disyaratkan $0,2 \%-1 \%$.

3. Berat Volume (SNI 1973:2008)

Hasil pengujian berat volume diperoleh hasil 1,81 kg/lt (lepas) dan 1,84 kg/lt (padat). Menurut SNI 1973:2008 berat volume yang disyaratkan untuk lepas dan padat 1,4-1,9 kg/lt. 


\section{Absorpsi (SNI 1969:2008)}

Hasil pengujian absorpsi diperoleh hasil 0,02\%. Berdasarkan SNI 1969:2008 absorpsi yang disyaratkan $3 \%$.

5. Berat Jenis (SNI 1969:2008)

Hasil pengujian berat jenis diperoleh hasil berat jenis curah kering 3,06 yang disyaratkan $(1,6-3,3)$, berat jenuh kering permukaan 3,13 yang disyaratkan $(1,63,4)$ dan berat jenis semu 3,28 dan yang disyaratkan (1,6-3,3) menurut SNI 1969:2008.

6. Abrasi (SNI 2417:2008)

Hasil pengujian abrasi atau keausan diperoleh hasil 25,02\%. Berdasarkan SNI 2417:2008 abrasi yang disyaratkan adalah $40 \%$.

\subsection{Komposisi Mix Design}

Komposisi mix desain beton merupakan metode pemilihan bahan untuk campuran beton dengan pertimbangan kualitas dengan tujuan beton bisa mencapai hasil yang telah ditetapkan. Dalam penelitian ini menggunakan acuan perhitungan beton mutu K-350. Hasil yang di dapat adalah 3 benda uji dengan ukuran $\mathrm{P} \times \mathrm{L} \times \mathrm{t}=60 \times 20 \times 10(\mathrm{~cm})$ dan 1 benda uji dengan ukuran $\mathrm{P} \times \mathrm{L} \times \mathrm{t}=60 \times 40 \times 5(\mathrm{~cm})$ memerlukan $27(\mathrm{Kg})$ semen, $40(\mathrm{Kg})$ pasir, $60(\mathrm{Kg})$ koral dan 13 (lt) air serta 3 wiremesh dengan ukuran $\mathrm{P} \times \mathrm{L}=58 \times 18(\mathrm{~cm})$.

\subsection{Kuat Tekan}

Pada pengujian kuat tekan pada pelat beton, menggunakan alat palu beton (Hammer Test, dengan 3 sampel benda uji yang berbentuk balok dengan ukuran seperti yang di paparkan pada abstrak. Hasil dari pengujian kuat tekan beton dapat disajikan pada Gambar 2. Dibawah ini :

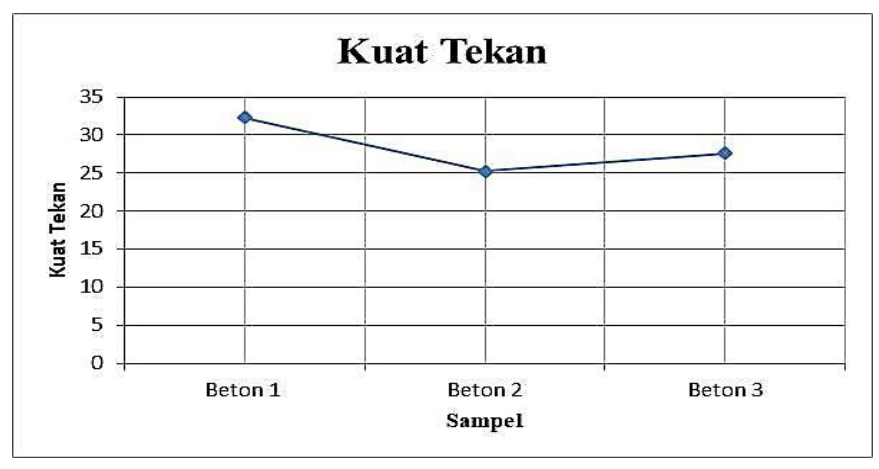

Sumber : Analisa Hasil Pengolahan Data Uji Kuat Tekan Beton

Gambar 2. Grafik Pengujian Kuat Pelat Tekan Beton 
Dari pengujian kuat tekan diperoleh hasil Sampel I 32,28 (MPa), Sampel II 25,25 (MPa) dan Sampel III 27,65 (Mpa).

\subsection{Kuat Tarik Wiremesh}

Pada pengujian kuat tarik wiremesh menggunakan alat Universal Testing Machine type TC-325 dengan daya 220 VAC. Adapun hasil dari pengujian kuat Tarik Wiremesh disajikan dalam Gambar 3. Dibawah ini :

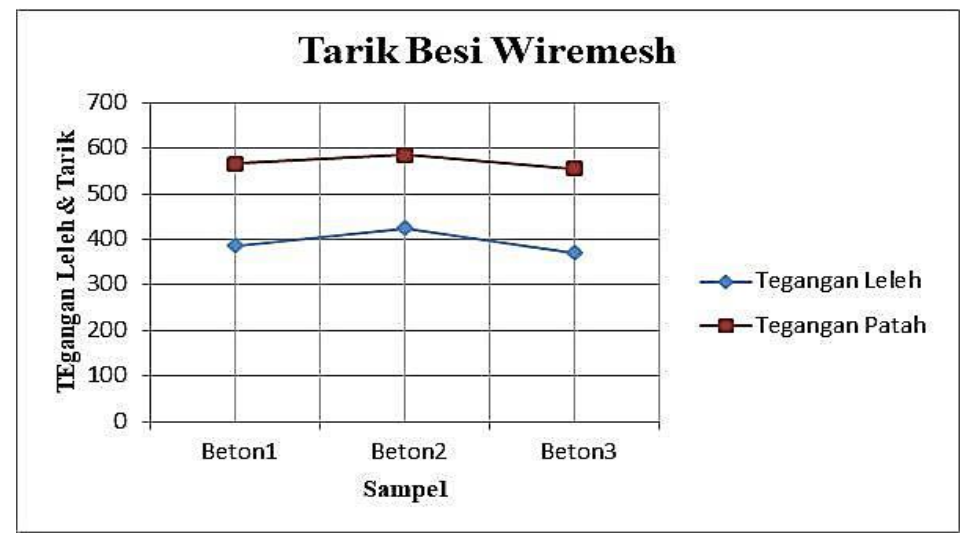

Sumber : Analisa Hasil Pengolahan Data Uji Kuat Tarik Wiremesh Beton

Gambar 3. Grafik Pengujian Kuat Tarik Besi Wiremesh

Dari pengujian kuat tari baja wiremesh diperoleh hasil sebagai berikut. Sampel I kuat tarik (Fu) 566,701 (MPa), kuateleh (Fy) 385,511 (MPa). Sampel II kuat tarik (Fu) 585,788 (MPa) dan kuat leleh (Fy) 424,484 (MPa). Sampel III kuat tarik (Fu) 555,414 (MPa) dan kuat leleh (Fy) 370,276 (MPa).

\subsection{Absorsi}

Pengujian absorpsi (rembesan) dilakukan untuk mencari hubungan rembesan dengan kuat tekan dari benda uji pelat beton itu sendiri. Adapun hasil dari pengujian absorsi disajikan dalam Gambar 4. Dibawah ini :

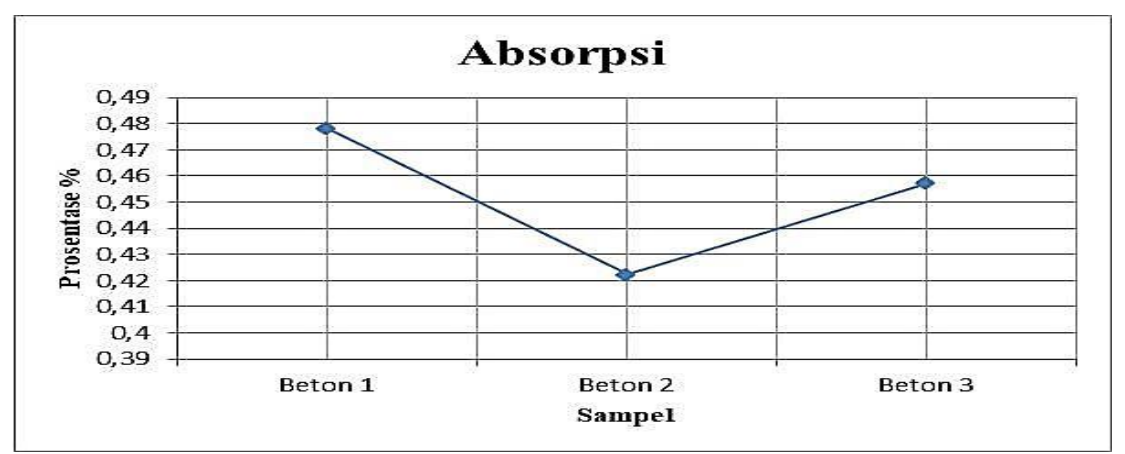

Sumber : Analisa Hasil Pengolahan Data Uji Absorpsi Beton

Gambar 4. Grafik Pengujian Absorpsi Pelat Beton 
Dari pengujian absorpsi diperoleh hasil Sampel I 0,48\%, Sampel II 0,42\% dan Sampel III 0,46\%. Serta hubungan antara nilai kuat tekan dengan absorpsi disajikan dalam Gambar 5. Dibawah ini :

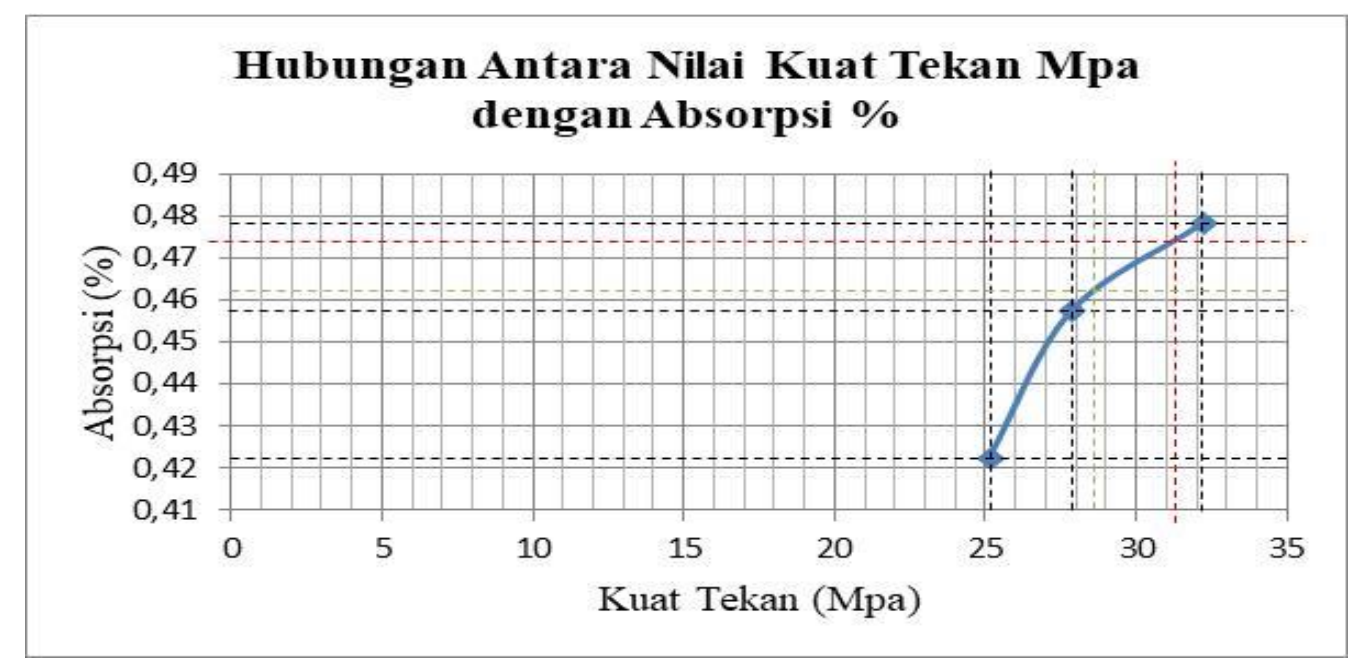

Sumber : Analisa Hasil Pengolahan Data Uji Kuat Tekan Dengan Absorpsi

Gambar 5. Grafik Hubungan Nilai Kuat Tekan dengan Absorpsi

Dari pengujian hubungan kuat tekan dengan absorpsi dapat disimpulkan semakin besar nilai kuat tekan beton mengakibatkan semakin besar daya absorpsi pada beton.

\subsection{Retakan dan Patahan}

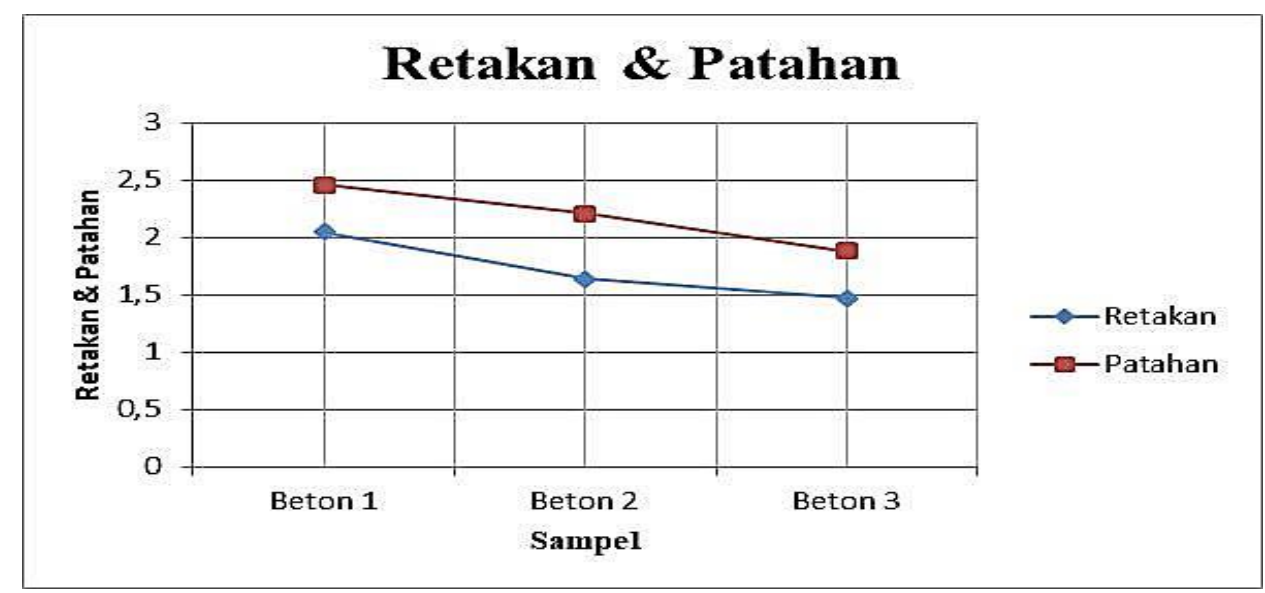

Sumber : Grafik Hasil Pengujian Retakan dan Patahan

Gambar 6. Grafik Pengujian Retakan dan Patahan Pelat Beton

Dari pegujian ini memperoleh hasil retakan dan patahan sebagai berikut, Sampel I retak saat menerima beban 2,04 (Mpa) dan patah saat menerima beban 2,45 (Mpa), Sampel II mengalami retakan saat menerima beban 1,64 (Mpa) dan patah saat menerima beban 2,21 (Mpa) dan Sampel III mengalami retakan saat menerima beban 1,48 (Mpa) dan patah saat menerima beban 1,88 (Mpa). 


\section{Kesimpulan dan Saran}

\subsection{Kesimpulan}

Berdasarkan hasil penelitian mengenai pengujian material, pembuatan benda uji, pengujian berat jenis, kuat tekan, kuat tarik besi, absorpsi dan retakan patahan yang dilakukan di Laboratorium Teknik Sipil Universitas Kadiri, dapat diambil kesimpulan sebagai berikut :

1. Pengujian kuat tekan beton menggunakan hammer test memperoleh hasil kuat tekan dengan rata-rata $(28,38 \mathrm{Mpa})$.

2. Pada pengujian kuat tarik wiremesh dengan diameter $4 \mathrm{~mm}$ bisa digunakan untuk tulangan pelat beton, karena memperoleh hasil tegangan leleh sebesar 393,423 MPa yang melebihi minimal tegangan leleh yang diijikan sebesar $240 \mathrm{MPa}$.

3. Pengujian absorpsi memperoleh nilai optimum sebesar $0,475 \%$.

4. Pada pengujian retakan dan patahan, retakan terjadi pada saat menerima beban ratarata sebesar 1,72 Mpa dan patahan terjadi saat menerima beban rata-rata 2,18 Mpa.

\subsection{Saran}

Berdasarkan hasil penelitian yang telah dilakukan dengan harapan agar penelitian ini dapat berkembang maka diberikan saran, dilakukan penelitian lebih lanjut untuk memperoleh hasil yang lebih maksimal seperti pengujian kuat tekan menggunakan alat compression machine serta untuk penelitian selanjutnya dapat dikembangkan dengan membuat sampel lebih dari 3 buah dan dilakukan uji tes kuat lentur beton menggunakan mesin flexture test (kuat lentur tes) agar mendapatkan hasil akurat. 


\section{Daftar Pustaka}

[1] A. U. Zhafira, "STUDI EKSPERIMENTAL PENGUJIAN KUAT TEKAN, KUAT TARIK BELAH DAN KUAT LENTUR PADA CAMPURAN BETON DENGAN PENAMBAHAN SERAT KAWAT BENDRAT BERKAIT,” Jrsdd, vol. 5, no. 4, p. 82, 2017, doi: 10.1017/CBO9781107415324.004.

[2] D. H. Prayogo, A. Ridwan, and S. Winarto, "PEMANFAATAN LIMBAH GYPSUM BOARD DAN BATU BATA MERAH UNTUK SUBSTITUSI SEMEN PADA PEMBUATAN BETON,” Jurmateks, vol. 2, no. 2, pp. 333-342, 2019.

[3] H. K. Sitompul, "Studi eksperimental pelat satu arah dengan steel fiber sebagai reinforcement," 2011.

[4] J. Hartono, I. Satyarno, and A. Triwiyono, "Perkuatan Lentur Pelat Lantai Tampang Persegi dengan Penambahan Tulangan Tarik dan Komposit Mortar (Flexural Strengthening of Rectangular Concrete Slab Using Tension Reinforcement and Composite Mortar)," Semesta Tek., vol. 13, no. 1, pp. 1-11, 2010.

[5] S. el unas A Nugroho, H Hasyim, “ANALISA PRODUKTIVITAS PEKERJAAN PELAT LANTAI M-PANEL, BETON BERTULANG, DAN SNI PEKERJAAN PELAT BETON BERTULANG,” J. Mhs. Jur. Tek. Sipil UB, vol. 1, no. 2, 2015.

[6] G. Li and J. Cheng, "A generalized analytical modeling of grid stiffened composite structures," J. Compos. Mater., vol. 41, no. 24, pp. 2939-2969, 2007.

[7] D. Menggunakan and T. Wire, "Kapasitas lentur lantai grid dengan menggunakan tulangan Wiremesh," Eprints UMS, 2013.

[8] Badan Standardisasi Nasional, TATA CARA PERHITUNGAN STRUKTUR BETON UNTUK BANGUNAN GEDUNG [SNI 03 - 2847 - 2002]. Surabaya, 2002.

[9] R. Listiyanto, “Tinjauan Momen Lentur Pelat Lantai Precast Beton Ringan Menggunakan Bahan Campuran Limbah Plastik Dan Pecahan Genteng Diperkuat Tulangan Wiremesh," Eprints UMS, vol. 3, no. 1, p. 9, 2017.

[10] I. M. I. Qeshta, P. Shafigh, and M. Z. Jumaat, "Flexural behaviour of RC beams strengthened with wire mesh-epoxy composite," Constr. Build. Mater., vol. 79, pp. 104$114,2015$.

[11] N. Lawler and M. A. Polak, "Development of FRP shear bolts for punching shear retrofit 
of reinforced concrete slabs," J. Compos. Constr., vol. 15, no. 4, pp. 591-601, 2011.

[12] A. A. Amiruddin, H. Parung, R. Djamaluddin, and R. Irmawaty, "OVERLAPPING TULANGAN PADA SEPERTIGA BENTANGAN TERHADAP PERILAKU LENTUR BALOK BETON BERTULANG MATERIAL RETROFIT WIREMESH DAN SCC," Puslantek, vol. 4, pp. 482-489, 2018.

[13] Q. L. Zhang, L. Hu, C. Hu, and H. G. Wu, "Low-cycle fatigue issue of steel spiral cases in pumped-storage power plants under China's and US's design philosophies: A comparative numerical case study," Int. J. Press. Vessel. Pip., vol. 172, no. December 2018, pp. 134-144, 2019.

[14] S. M. MOSAVI and A. SADEGHI NIK, "Strengthening of steel-concrete composite girders using carbon fibre reinforced polymer (CFRP) plates," Sadhana - Acad. Proc. Eng. Sci., vol. 40, no. 1, pp. 249-261, 2015.

[15] Y. S. Kandi and R. Ramang, "SUBSTITUSI AGREGAT HALUS BETON MENGGUNAKAN KAPUR ALAM DAN MENGGUNAKAN PASIR LAUT PADA CAMPURAN BETON (Studi Analisis Bahan Kapur Alam dan Pasir Laut Dari Kabupaten Sumba Barat Daya Provinsi Nusa Tenggara Timur),” J. Tek. Sipil, vol. 1, no. 4, pp. 74-86, 2012.

[16] M. A. Anshori, A. Ridwan, and Y. C. S. P, "PENELITIAN UJI KUAT TEKAN BETON DENGAN MEMANFAATKAN AIR LIMBAH TETES TEBU DAN ZAT ADDITIVE CONCRETE,” Jurmateks, vol. 2, no. 1, pp. 16-27, 2019.

[17] Achmad Hasyim. Dwi Kartikasari, "PEMBUATAN BETON CAMPURAN STYROFOAM MENGGUNAKAN AGREGAT PASIR BENGAWAN SOLO,” UKaRsT, vol. 4, no. 1, 2020.

[18] N. Faqih and C. Ahmad, "Tinjauan Pemanfatan Trass Sebagai Bahan Pengganti Sebagian Semen Terhadap Kuat Tekan Beton,” J. PPKM, pp. 131-136, 2014.

[19] Supriadi, Y. C. S. P, A. Ridwan, and A. I. Candra, "PENELITIAN PENAMBAHAN BAHAN BATU PADAS PADA CAMPURAN ASPAL BETON," Jurmateks, vol. 2, no. 1, pp. 154-163, 2019.

[20] M. N. Ikhsan, H. Prayuda, and F. Saleh, "Pengaruh Penambahan Pecahan Kaca Sebagai Bahan Pengganti Agregat Halus dan Penambahan Fiber Optik Terhadap Kuat Tekan Beton Serat,” J. Ilm. SEMESTA Tek. Vol. 19, No. 2, 148-156, Novemb. 2016, vol. 19, no. 
2, pp. 148-156, 2016.

[21] B. S. Herry Widhiarto, “Analisis Campuran Beton Berpori Dengan Agregat Bergradasi Terpisah Ditinjau Terhadap Mutu dan Biaya," Extrapolasi J. Tek. Sipil Untag Surabaya, vol. 05, no. 02, pp. 24-30, 2012.

[22] E. Tri, N. Nugroho, S. Suryokusumo, D. P. Lestari, L. Karlinasari, and D. S. Nawawi, "Pengaruh Komponen Kimia dan Ikatan Pembuluh terhadap Kekuatan Tarik Bambu," J. Tek. Sipil ITB, vol. 23, no. 1, pp. 31-40, 2016.

[23] A. Amiruddin, "Metode Retrofit Dengan Wire Mesh Dan SCC Untuk Peningkatan Kekuatan Lentur Balok Beton Bertulang,” J. Tenik Sipil, pp. 1-6, 2012.

[24] Badan Standarisasi Nasional, "Metode Pengujian Elemen Struktur Beton dengan Alat Palu Beton Tipe N dan NR (Sni 03-4430-1997),” p. BSN, 1997.

[25] Badan Standardisasi Nasional, "Metode uji angka pantul beton keras ( ASTM C 805-02 )," pp. 1-10, 2010.

[26] SNI 07-2529-1991, "Metode pengujian kuat tarik baja beton," Standar Nas. Indones., p. $15,1991$.

[27] A. Maryoto, "PENURUNAN NILAI ABSORBSI DAN ABRASI BETON DENGAN PENAMBAHAN CALCIUM STEARATE DAN FLY ASH,” Media Tek. Sipil, vol. 9, 2009.

[28] F. P. Pane, H. Tanudjaja, and R. S. Windah, "Pengujian Kuat Tarik Lentur Beton Dengan Variasi Kuat Tekan Beton,” J. Sipil Statik, vol. 3, no. 5, pp. 313-321, 2015. 